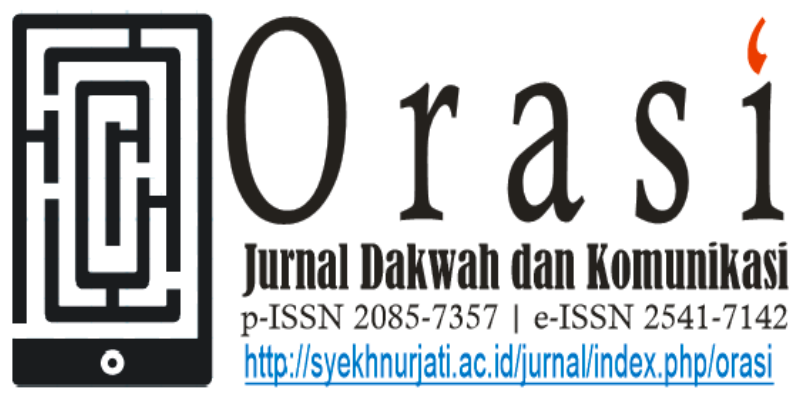

Volume 9 No. 2, PP 129 - 146; November 2018

\title{
EKSISTENSI KOMUNITAS MELALUI BUDAYA ORGANISASI
}

\author{
Abdul Basith1(*), Khoirul Anwarudin2 \\ Dosen Jurusan Komunikasi dan Penyiaran Islam ${ }^{1}$ \\ Mahasiswa Jurusan Komunikasi dan Penyiaran Islam ${ }^{2}$ \\ Fakultas Ushuluddin Adab dan Dakwah IAIN Syekh Nurjati Cirebon \\ abdul.basit@syekhnurjati.ac.id ${ }^{\left({ }^{*}\right)}$, khoirul.anwarudin.st@syekhnurjati.ac.id
}

\begin{abstract}
ABSTRAK
Dalam lingkup yang lebih kecil seperti Organisasi, proses komunikasi juga menghasilkan pola dan budaya yang mengatur dan mengikat terhadap sebuah kelompok masyarakat. Budaya yang pada akhirnya disebut sebagai budaya Organisasi. Dimana norma, nilai nilai, dan perilaku dalam organisasi atau perusahaan bersifat mengikat dan menjadi sebuah identitas tersendiri. Penerapan budaya organisasi yang baik tentu akan berpengaruh terhadap keberadaan atau eksistensi suatu organisasi atau komunitas di lingkungan masyarakat. Pada penelitian ini mengkaji dua pertanyaan penelitian yaitu (1) Bagaimana budaya organisasi di komunitas paduan suara Satya Gaura Svara Choir Cirebon yang dianalisis berdasarkan pendekatan level budaya organisasi menurut Cumming dan Worley. (2) Bagaimana budaya organisasi berperan dalam menjaga eksistensi komunitas paduan suara Satya Gaura Svara Choir Cirebon.Untuk menganalisis penelitian ini peneliti menggunakan metode penelitian kualitatif, pendekatan yang digunakan dalam penelitian ini adalah studi kasus. Hasil dari penelitian ini menunjukan bahwa budaya organisasi berperan penting dalam menjaga eksistensi komunitas paduan suara Satya Gaura Svara Choir (SGSC) Cirebon. nilai nilai kebersamaan merupakan nilai yang paling ditekankan dan dianggap penting untuk disebarkan kepada seluruh anggota, sehingga budaya organisasi yang diterapkan turut membantu Keberhasilan organisasi dalam mempertahankan dan memajukan komunitas, keberhasilan dalam menjaring anggota, berjalanya fungsi manajemen, Keberhasilan dalam prestasi yang diperoleh, dapat menonjolkan produk sanggar kepada masyarakat, serta dapat diterima oleh masyarakat.
\end{abstract}

Kata kunci: Budaya Organisasi, Komunikasi, Komunitas, Paduan Suara, Eksistensi 


\section{PENDAHULUAN}

Manusia adalah mahluk sosial.

Karena itu, manusia senantiasa berhubungan dengan manusia lainnya, untuk mendapatkan informasi mengenai lingkungannya, dirinya dan orang-orang disekitarnya. Untuk mendapatkan informasi tentu setiap individu perlu melakukan komunikasi dengan individu lain. Komunikasi sangat penting perannya bagi kehidupan sosial, budaya, politik dan pendidikan, karena komunikasi merupakan proses transaksional yang mempengaruhi prilaku tertentu sebagai konsekwensi dari hubungan social (Uchjana, 1993).

Komunikasi sangat penting perananya bagi kehidupan sosial, tradisi, politik dan pendidikan, karena komunikasi merupakan proses dinamika transaksional yang mempengaruhi perilaku, yang mana sumber dan penerimaannya sengaja menyandi (to code) perilaku mereka untuk menghasilkan pesan yang mereka salurkan melalui suatu saluran (Channel) guna merangsang atau memperoleh sikap atau perilaku tertentu sebagai konsekwensi dari hubungan sosial (Mulyana, 1990:15).

Dalam hubunganya dengan proses sosial, komunikasi menjadi sebuah cara dalam melakukan perubahan sosial (social change). Komunikasi berperan menjembatani perbedaan dalam masyarakat karena mampu melekatkan kembali sistem sosial masyarakat dalam usahanya melakukan perubahan. Namun begitu, komunikasi juga tak akan lepas dari konteks sosialnya. Artinya, ia akan diwarnai oleh perilaku, pola, norma, dan pranata masyarakatnya (Ngalimun, $2016: 131)$.

Dalam lingkup yang lebih kecil seperti Organisasi, proses komunikasi juga menghasilkan pola dan budaya yang mengatur dan mengikat terhadap sebuah kelompok masyarakat. Budaya yang pada akhirnya disebut sebagai budaya Organisasi. Dimana norma, nilai nilai, dan perilaku dalam organisasi atau perusahaan bersifat mengikat dan menjadi sebuah identitas tersendiri.

Budaya menjadi sumber inspirasi, kebanggaan dan sumber daya bagi siapapun terutama bagi kalangan internal suatu komunitas, budaya juga menjadi kekuatan penggerak yang mampu membangkitkan semangat juang untuk memerdekakan dan memajukan suatu daerah atau suatu negara (Umam, 2010) 
Menurut Edgar Schein (1985)

budaya organisasi adalah pola asumsi dasar yang ditemukan atau dikembangkan oleh suatu kelompok orang selagi mereka belajar untuk menyelesaikan problem problem, menyesuaikan diri dengan lingkungan eksternal dan berintegrasi denga lingkungan internal. Asumsi dasar tersebut terbukti dapat dengan baik untuk menyelesaikan masalah yang dihadapinya dan dianggap valid. Oleh karena itu hal tersebut dapat diajarkan kepada anggota baru sebagai cara yang tepat dalam merepersepsikan, berpikir dan memiliki pemahaman yang kuat dalam hubunganya dengan problem tersebut.

Sementara itu, wirawan (2007) mendefinisikan budaya organisasi sebagai norma, nilai nilai, asumsi, kepercayaan, filsafat, kebiasaan organisasi dan sebagainya. Isi budaya organisasi yang dikembangkan dalam waktu yang lama oleh pendiri, pemimpin dan anggota organisasi dalam memproduksi produk, melayani Konsumen dan mencapai tujuan organisasi.

Penerapan budaya organisasi yang baik tentu akan berpengaruh terhadap keberadaan atau eksistensi suatu organisasi atau komunitas di lingkungan masyarakat. Eksistensi yang dimaksud dapat berupa penambahan jumlah anggota, ataupun pencapaian prestasi yang baik sehingga diakui atau ditanggapi secara positif oleh masyarakat sekitar.

Komunitas sendiri merupakan sekelompok orang yang saling berinteraksi secara sosial berdasarkan kesamaan kebutuhan atau tujuan bersama dan adanya wilayah individu tertentu yang terbuka untuk anggota kelompok lain (Nasrullah, 2012) misalnya waktu. Suatu kelompok biasanya terbentuk karena adanya kesamaan hobi, tempat tinggal, asal daerah maupun ketertarikan pada suatu hal tertentu, salah satunya adalah Paduan Suara.

Paduan suara pada umumnya dipandang sebagai suatu wadah kegiatan seni suara, dimana keanggotaan berfungsi untuk suatu tujuan paduan suara. Paduan suara seyogyanya berfungsi sebagai penyampai pesan pesan dan kesan dari komponis didalam karya musik yang diciptakanya, disampaikan kepada para pendengar melalui anggota anggota paduan suara.

Bukan hanya sebagai penyampai pesan, paduan suara juga turut mengharumkan nama Indonesia di kancah Internasional. Melalui paduan suara, kelompok paduan suara 
anak The Rezonans Children's Choir (TRCC) berhasil menorehkan prestasi sebagai juara di kompestisi paduan suara Musica Eterna Roma International Festival \& Competition 2017. Selain sebagai juara umum, Kelompok paduan suara yang terdiri dari anak anak berusia 10-17 tahun tersebut juga berhasil memenangkan dua kategori yang diikuti, yaitu kategori Children's Choir dan kategori Gospel and Spirituals. Festival yang diselenggarakan di kota Roma Italia tersebut diikuti oleh 15 kelompok peserta dari 12 negara. 1

Sementara itu, paduan suara Institut Teknologi Bandung juga pernah mengharumkan nama indonesia dengan memenangkan lima penghargaan dalam kompetisi 5th Florence International Choir Festival (FICF) 2016 di Italia. Lima penghargaan yang diperoleh yaitu medali emas untuk kategori Youth Choir dan Popular, Folk, Gospel, Barbershop Ensambles. Sementara tiga penghargaan lainya yaitu Best Italian Composer Performance, Best

1

https://www.cnnindonesia.com/hiburan/20170 709172238-241-226642/paduan-suaraindonesia-the-resonanz-raih-juara-umum-diroma diakses pada 26 januari 2018 pukul 10:24
Contemporary Arrangement, dan Best Costume. 2

Banyaknya prestasi yang telah ditorehkan generasi muda di kancah internasional, tentunya memberikan banyak inspirasi bagi orang lain. salah satunya adalah bagi anggota komunitas paduan suara Satya Gaura Svara Choir Cirebon.

Komunitas Paduan suara Satya Gaura Svara Choir (SGSC) adalah Komunitas paduan suara pertama yang ada di wilayah Cirebon (Kabupaten dan Kota). Komunitas dibentuk pada tanggal 11 November 2014 oleh beberapa Mahasiswa Anggota Unit Kegiatan Mahasiswa (UKM) Seni dan Budaya Universitas Swadaya Gunung Jati (Unswagati) Cirebon. Berbeda dengan kelompok paduan suara atau Choir yang dibentuk sebagai kegiatan intra sekolah, UKM pada sebuah Kampus atau Gereja, yang bersifat ekslusif. SGSC Cirebon justru dibentuk untuk mewadahi minat dan bakat mahasiswa yang ada di wilayah Cirebon (Kabupaten dan Kota) dalam bidang bernyanyi.

Sebagai sebuah komunitas yang telah eksis selama lebih dari 4 tahun,

2

https://www.itb.ac.id/news/read/5229/home/p aduan-suara-mahasiswa-itb-juarai-5th-florenceinternational-choir-festival-di-italia diakses pada 26 januari 2018 pukul 10:40 
hingga saat ini SGSC Cirebon telah memiliki sebanyak 48 anggota aktif yang oleh kelompok tersebut disebut member. Member dipilih melalui audisi yang diadakan setiap tahun untuk mencari bakat bakat baru serta menggantikan posisi member member sebelumnya yang mundur karena alasan telah berakhirnya masa belajar mereka di perguruan tinggi ataupun alasan lainya.

Untuk menunjang kekompakan dan keakraban antar member, komunitas SGSC Cirebon rutin menggelar kegiatan seperti latihan yang dilakukan setiap hari senin dan sabtu, rapat pengurus, kongkowkongkow maupun kegiatan buka bersama setiap bulan Ramadhan. Selain itu, mereka sering menyebut sesama member sebagai saudara karena kedekatan yang terjalin cukup kuat. Hal tersebut adalah beberapa strategi kelompok tersebut untuk menjaga kekompakan demi tercapainya tujuan3.

Kini, komunitas paduan suara Satya Gaura Svara Choir Cirebon dianggap telah menjadi kelompok paduan suara yang disegani di wilayah Cirebon. Terbukti, hampir setiap kali

3 Berdasarkan wawancara dengan Moh. Alvi Yasin dan Siviyanti, pengurus komunitas SGSC pada tanggal 25 mei 2017 ada event-event Hari Besar keagamaan maupun Hari Besar Nasional yang diselenggarakan oleh pemerintah daerah maupun instansi lainya, paduan suara Satya Gaura Svara Choir Cirebon selalu dipercaya untuk mengisi acara acara tersebut. Tentunya eksistensik komunitas tersebut tidak terlepas dari budaya komunikasi yang telah diterapkan untuk menjaga kekompakan serta diantara pengurus dengan member, maupun diantara member dengan member, serta menjaga eksistensi keberadaan mereka di tengah tengah masyarakat sebagai Komunitas Paduan suara pertama dan satu satunya yang ada di wilayah Cirebon.

\section{METODE PENELITIAN}

\section{Jenis Penelitian}

Jenis penelitian yang digunakan adalah kualitatif. Gunawan menyebutkan pendapat Bogdan dan Taylor mengenai penelitian kualitatif. Prosedur penelitian yang menghasilkan data deskriptif berupa kata-kata tertulis atau lisan dari orang-orang dan perilaku yang diamati yang diarahkan pada latar dan individu secara holistik (Gunawan, 2015: 82).

Dalam penelitian kualitatif yang berlandaskan pada filsafat postpositivisme, merupakan suatu realitas yang tidak dapat dipecah 
kedalam beberapa bagian (Sugiyono, 2010: 17).

Penelitian Kualitatif merupakan penelitian yang memiliki sasaran penelitian yang terbatas, tetapi dengan keberhasilan itu digali sebanyak mungkin data mengenai sasaran penelitian. (Bungin, 2001: 11).

Pada penelitian kualitatif, peneliti akan fokus pada keseluruhan situasi sosial yang meliputi tiga aspek yaitu tempat (place), pelaku (actor), dan aktivitas (activity) yang berinteraksi secara sinergis (Sugiyono, 2009:207).

Sehingga dapat disimpulkan bahwa penelitian kualitatif adalah penelitian terhadap suatu realitas baik berupa orang, lembaga maupun peristiwa yang menghasilkan data deskriptif berupa kata kata dari orang orang orang yang dan perilaku yang diamati secara holistik.

\section{Pendekatan Penelitian}

Dalam setiap kegiatan ilmiah, agar lebih terarah dan rasional diperlukan sebuah metode yang sesuai dengan metode yang sesuai dengan objek penelitian, karena metode berfungsi sebagai cara mengerjakan sesuatu dalam upaya mendapatkkan hasil hasil yang optimal dan data data yang akurat (Suprayogo, 2003: 99).

\section{Teknik Analisis Data}

Teknik Analisis Data adalah suatu cara yang dilakukan dengan jalan bekerja dengan data, mengorganisasikan data, memilah milahnya menjadi satu kesatuan yang dapat dikelola, mensintesiskanya, mencari dan menemukan pola, menemukan apa yang penting, dan apa yang dipelajari, dan memutuskan, apa yang dapat diceritakan, kepada orang lain (Moleong, 2010 : 248)

Begitupun dengan Raco (2010 : 121) yang menyatakan bahwa teknik analisis data adalah mengatur secara sistematis data yang diperoleh dari wawancara dan observasi, menafsirkan dan menghasilkan suatu pemikiran, pendapat, teori atau gagasan yang baru.

Teknik analis data dalam penelitian Kualitatif dilakukan secara interaktif dan berlangsung terus menerus sampai tuntas. Menurut miles dan huberman ada tiga langkah dalam proses analisis data (sugiyono, 246-252) yaitu: reduksi data, penyajian data, dan pengambilan kesimpulan.

\section{Validasi Data}

Raco (2010: 134) menjelaskan bahwa untuk menguji keabsahan atau validitas hasil penelitian terdapat tiga cara atau metode yaitu dengan melakukan Triangulasi, Member Cecking dan Auditing. Triangulasi dibedakan menjadi 
tiga yaitu Triangulasi Data/Sumber, Triangulasi Metode dan Triangulasi Teori. Dalam penelitian yang menggunakan metode Kualitatif dengan studi deskriptif atau studi kasus maka metode validasi yang digunakan oleh peneliti adalah Triangulasi Sumber data.

Dalam penelitian ini, untuk menguji validitas data digunakan teknik dan data yang diperoleh dengan menggunakan suatu metode tertentu, misalnya catatan lapangan yang dibuat selama melakukan observasi, dengan data yang diperoleh dengan menggunakan metode lain, misalnya transkrip dari indepth interview, mengenai suatu persoalan dari sumber yang sama. Dalam hal ini peneliti sebenarnya berusaha menguji seberapa tingkat reliabilitas data dengan menggunakan metode yang berbeda (Pawito, 2007: 99).

\section{Informan/Responden}

Apabila peneliti menggunakan kuesioner atau wawancara dalam pengumpulanya maka sumber data disebut responden atau informan, yaitu orang yang merespon atau menjawab pertanyaan peneliti, baik penelitian lisan maupun tulisan (Arikunto, 2010 : 172).

Penentuan informan atau Responden dalam penelitian ini akan dilakukan secara purposive sampling, teknik purposive sampling sendiri berarti peneliti memilih informan menurut ah ditetapkan, kriteria ini harus sesuai topik penelitian. Mereka yang terpilih berarti dianggap telah kredibel untuk menjawab pertanyaan yang menjadi fokus penelitian.

Adapun penentuan informan dalam penelitian ini dilakuka dengan teknik purposive sampling diman informan dipilih secara sengaja berdasarkan yang telah ditentukan sebelumnya. Dalam penelitian ini kriteria pemilihan informan didasarkan pada hal hal berikut :

1. Informan mengetahui banyak informasi tentang komunitas paduan suara SGSC yang terkait dengan fokus penelitian.

2. Informan berkedudukan sebagai pendiri, pengurus dan anggota.

3. Informan memiliki banyak waktu dan kesempatan untuk dimintai keterangan dan data terkait fokus penelitian.

\section{Objek Penelitian}

Objek penelitian merupakan fokus masalah yang akan dicari jawabanya melalui penelitian ini. Berdasarkan latar belakang masalah diatas, bahwa fokus masalah dari penelitian ini adalah bagaimana budaya organisasi yang diterapkan dapat berperan dalam menjaga eksistensi suatu komunitas. Dengan kata lain, obyek penelitian ini adalah segala bentuk budaya organisasi yang diterapkan pada komunitas paduan suara Satya Gaura Svara Choir (SGSC) Cirebon. 


\section{HASIL DAN PEMBAHASAN}

Budaya organisasi adalah seperangkat norma, nilai nilai, asumsi dan keyakinan yang dikebambangkan dan disebarluaskan kepada seluruh anggota organisasi guna mengatasi masalah mereka dalam berinteraksi dan mempertegas setiap anggota dalam merespon lingkungan demi suatu tujuan bersama.

Budaya organisasi yang baik tentu akan memberikan efek yang positif terhadap organisasi atau komunitas itu sendiri. Begitupun sebaliknya. Hal ini menunjukan bahwa budaya organisasi memberikan dampak yang cukup signifikan terhadap proses operasional organisasi.

Sebagai sebuah komunitas yang telah berdiri selama 4 Tahun, komunitas Satya Gaura Svara Choir (SGSC) Cirebon tentu telah mempunyai corak budaya yang khas, yang membedakanya dengan komunitas komunitas atau kelompok kelompok lainya. Budaya Organisasi yang dimaksud terbentuk melalui pertunjukan komunikasi tertentu yang dilakukan oleh anggota komunitas tersebut yang meliputi Ritual (Personal, Kerja, Sosial dan Organisasi), Passion, Sosial, Politik dan Enkulturasi.

Dalam melakukan penelitian, peneliti menggunakan pendekatan level budaya organisasi untuk memudahkan peneliti dalam mendeskripsikan budaya organisasi yang ada di komunitas Satya Gaura Svara Choir (SGSC) Cirebon. Dimana level budaya organisasi terdiri dari (1) Artefak, (2) Norma, (3) Nilainilai, dan (4) Asumsi Dasar.

Artefak adalah dimensi isi budaya organisasi yang dapat ditangkap dengan pancaindera. Terdiri dari objek material (logo, produk brosur, laporan tahunan dan benda seni dari organisasi). Rancangan fisik (bangunan, arsitektur gedung, dan tata ruang). Simbol simbol (kata kata, objek dan kondisi yang mempunyai arti bagi organisasi misalnya, logo, lambang, bendera organisasi, tanda pangkat, pakaian kebesaran, seragam dan sebagainya.

Artefak tidak saja berupa arsitektur bangunan atau tata ruang saja. Melainkan juga perilaku anggota organisasi yang dapat diamati seperti cara berpakaian.

Sebagai sebuah komunitas yang sering menampilkan pertunjukan Paduan Suara, pakaian dan aksesoris yang dikenakan memiliki peranan penting dalam membentuk identitas dan citra komunitas.

Menurut Informan 5, komunitas Satya Gaura Svara Choir (SGSC) Cirebon memiliki dua seat kostum pentas bagi masing masing anggota, Dresscode, Alat alat make up, aksesoris ikat bali dan 
kereta troli yang digunakan untuk mengangkut barang barang keperluan pementasan.

"Nah kebetulan, saya inventaris, jadi di SGSC tuh udah punya kostum 2. Ya bisa di mix sih. Dresscode juga. Selain itu ada make up, aksesoris, ikat bali gitu. Sama troli buat ngangkit ngangkut supaya gampang" 4

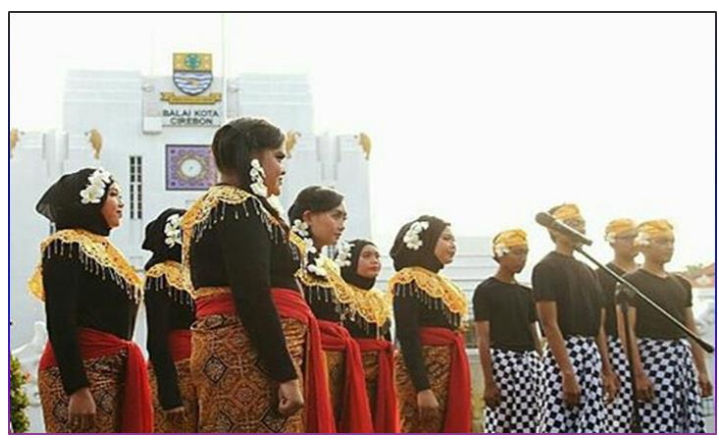

Gambar 2. Pementasan paduan suara oleh komunitas Satya Gaura Svara Choir (SGSC) Cirebon di Balai kota Cirebon dalam rangka memperingati Hari Ulang Tahun Kota Cirebon pada tanggal 1 November 2015. (Dok. Tim Dokumentasi SGSC)

Salah satu kostum yang sering digunakan oleh Komunitas paduan suara Satya Gaura Svara Choir (SGSC) Cirebon saat melakukan pementasan, merupakan kostum tradisional daerah yang terdiri dari kain poleng yaitu kain bermotif papan catur yang merupakan kain khas dari daerah bali serta udeng Bali yang dipakai oleh anggota laki laki serta kain tapih, bolero atau kain brukat yang dimodifikasi menjadi aksesoris di leher serta ornamen kembang goyang khas Bali untuk anggota perempuan yang juga ditambahkan

\footnotetext{
4 Hasil wawancara dengan Dika Dani Septiati pada hari seni tanggal 26 Februari 2018 pukul 17.30 di Gedung Kesenian Rarasantang Kota Cirebon.
}

kerudung untuk anggota yang terbiasa berkerudung. Serta kain manset berwarna hitam.

Sementara satu seat pakaian pentas lain terdiri dari kebaya kutu baru dan kain tapih batik untuk anggota perempuan dan kain beskap jawa berwarna hitam serta kain tapih batik dikenakan oleh anggota laki laki. Sebagaimana yang diungkapkan oleh Informan 3.

"Selain satu seat pakaian Bali-bali gitu, disini kita juga punya pakaian buat pentas itu ada kebaya kutu baru sama bawahanya pakai kain tapih batik itu untuk anak anak cewek, kalo yang cowo pake beskap jawa warna hitam sama kain tapih juga"5

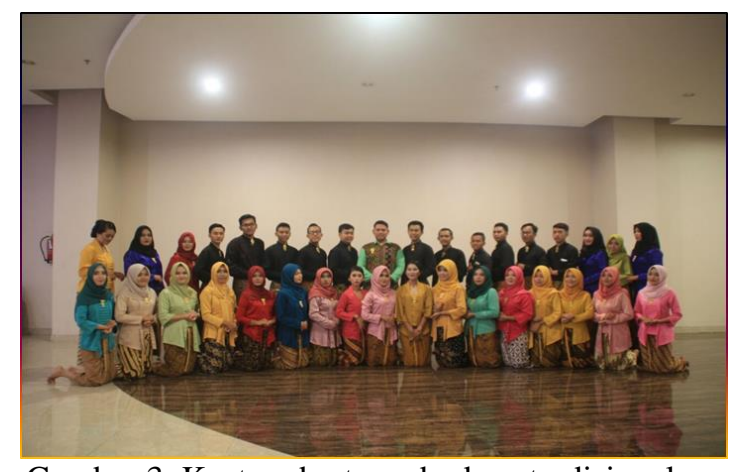

Gambar 3. Kostum bertema budaya tradisional daerah merupakan salah satu ciri komunitas Satya Gaura Svara Choir (SGSC) Cirebon. (Dok. Tim Dokumentasi SGSC)

Penggunaan baju baju tradisional sebagai kostum pentas oleh komunitas paduan suara Satya Gaura Svara Choir (SGSC) Cirebon dimaksudkan untuk mencocokan dengan lagu lagu yang

\footnotetext{
5 Hasil wawancara dengan Fifta Haifa, pada hari rabu tanggal 28 Februari pukul 16.00 di Gedung Kesenian Rarasantang Kota Cirebon
} 
dibawakan, yaitu jenis lagu lagu folklore dan lagu lagu nasional. Sebagaimana yang diungkapkan oleh Informan 2.

"Kenapa kita pake baju baju tradisional gitu untuk pentas? Karena kita kan paduan suara yang emang dari awal ngusung lagu folklore. Folklore tuh kayak lagu rakyat yah, contohnya yang sering kita bawakan itu ada lagu Bungong Jeumpa dari Aceh, lagu Janger dari Bali sama Jali-jali dari Jakarta. Selain itu kita juga sering bawain lagu Nasional kayak lagu Indonesia Pusaka itu favorit banget". 6

Dari hasil wawancara diatas dan observasi yang dilakukan oleh peneliti, dapat disimpulkan bahwa artefak yang dimiliki oleh komunitas paduan suara Satya Gaura Svara Choir (SGSC) berupa keperluan pentas seperti kostum adat kebaya, kain batik, bolero, aksesoris ikat kepala bali, kembang goyang dan sebagainya.

Norma adalah peraturan, tata nilai, ketentuan, standar dan pola perilaku yang menentukan perilaku yang dianggap pantas dan tidak pantas dalam merespond sesuatu. Norma organisasi sangat penting bagi organisasi karena mengatur anggota organisasi. Normalah yang mengikat budaya organisasi sehingga setiap perilaku organisasi dapat diramalkan dan dikontrol.

6 Hasil wawancara dengan Silviyanti, pada hari rabu 28 Februari 2018 pada pukul 17.30 di Gedung Kesenian Rarasantang, Kota Cirebon
Pendapat serupa diungkapkan oleh Widjaja (1985) yang menyatakan bahwa Norma adalah petunjuk tingkah laku yang harus dilakukan dan tidak boleh dilakukan dalam hidup sehari-hari, berdasarkan suatu alasan (motivasi) tertentu dengan disertai sanksi. Sanksi adalah ancaman/akibat yang akan diterima apabila norma tidak dilakukan.

Dalam kehidupan umat manusia terdapat bermacam-macam norma, yaitu norma agama, norma kesusilaan, norma kesopanan, norma hukum dan lain-lain. Norma agama, norma kesusilaan, norma kesopanan, dan norma hukum digolongkan sebagai norma umum. Selain itu dikenal juga adanya norma khusus, seperti aturan permainan, tata tertib sekolah, tata tertib pengunjung tempat bersejarah dan lain-lain.

Setiap orang memiliki nilai utama dalam dirinya yang sadar atau tidak menggerakkannya pada pilihan untuk tertuju pada apa yang paling dianggapnya tepat bagi hidupnya. Bisa dikatakan bahwa nilai-nilai adalah, segala sesuatu yang dipikir, dirasa, dan dilakukan, yang secara personal hal itu dianggap penting, berharga, bermakna, dan membahagiakan. Maka nilai utama adalah nilai diri yang paling menonjol dalam mengarahkan seseorang pada cara hidupnya. Nilai utama personal inilah yang akan selalu berjumpa dan 
berinteraksi dengan nilai utama yang dimiliki orang lain. Begitu seterusnya, hingga negosiasi nilai-nilai utama personal itu membentuk sebuah sistem nilai bersama dalam komunitas, menghasilkan karakter-karakter unik orang-orangnya, pun karakter komunitas tersebut (Budiprabowo, 2017).

Selanjutnya Daroeso (dalam Afriyanto, 2013) mengemukakan bahwa nilai memiliki tiga sifat dasar, di antaranya: (1) nilai itu suatu realitas abstrak dan ada dalam kehidupan manusia. Nilai yang bersifat abstrak tidak dapat diindrakan. Hal yang dapat diamati hanyalah objek yang bernilai itu sendiri, misalnya, orang yang memiliki kejujuran. Kejujuran adalah nilai, tetapi kita tidak bisa mengindra; (2) Nilai memiliki sifat normatif, artinya nilai mengandung harapan, cita-cita, dan suatu keharusan sehingga nilai nemiliki sifat ideal (das sollen). Nilai diwujudkan dalam bentuk norma sebagai landasan manusia dalam bertindak. Misalnya, nilai keadilan. Semua orang berharap untuk mendapatkan dan berperilaku yang mencerminkan nilai keadilan, serta (3) Nilai berfungsi sebagai daya dorong/motivator dan manusia adalah pendukung nilai. Manusia bertindak berdasar dan didorong oleh nilai yang diyakininya.
Asumsi dasar bisa dikatakan asumsi yang tersirat yang membimbing bagaimana organisasi bertindak dan berbagi kepada anggota bagaimana mereka melihat, berfikir dan merasakan. Asumsi dasar seperti sebuah teori yang digunakan, tidak dapat diperdebatkan dan sulit unuk dirubah (Schein, 2010)

Asumsi adalah dugaan yang dianggap benar dan diterima sebagai dasar berfikir dan bertindak. Asumsi mempengaruhi persepsi, perasaan dan emosi anggota organisasi. Keyakinan pendiri menjadi sumber terbentuknya asumsi dasar dalam sebuah organisasi.

\section{Peran Budaya Organisasi dalam Mempertahankan Komunitas}

Sejak berdiri pada tanggal 1 november 2014, komunitas paduan suara Satya Gaura Svara Choir (SGSC) Cirebon telah mengalami banyak hal. Budaya organisasi dianggap telah memberikan dampak yang positif terhadap perkembangan komunitas. Dengan menjunjung nilai nilai kebersamaan, melalui ritual sosial dan ritual organisasi seperti berkumpul, rapat bersama, makan bersama, jalan jalan dan sebagainya diharapkan anggota komunitas tersebut menjadi lebih terikat secara emosional dengan anggota lainya yang tentu saja berdampak pada soliditas serta komitmen yang tinggi kuat untuk mempertahankan keanggotaannya dalam organisasi dan 
bersedia melakukan usaha yang tinggi demi pencapaian tujuan bersama yang diinginkan.

Hal ini sesuai dengan apa yang disampaikan oleh Informan 2.

"Saya sebagai salah satu orang yang ikut mendirikan SGSC, merasa bangga dengan komunitas ini. Kita mulai dari nol dan sekarang orang orang banyak yang mengenal SGSC, mengenal paduan suara dan juga cinta dengan paduan suara. Ya bisa dibilang kalau tujuan kita membentuk komunitas ini udah tercapai, tinggal bagaimana anak anak penerus SGSC bisa memepertahankan eksistensi, kalau bisa ya lebih maju dan maju lagi"7

Selain itu dengan mengenakan atribut yang terkait dengan komunitas seperti kaos seragam, pakaian pentas, syal, lambang dan sebagainya juga merupakan upaya dalam memperkenalkan paduan suara di lingkungan masyarakat.

Telah tercapainya tujuan komunitas tersebut, yaitu memperkenalkan dan mengembangkan seni paduan suara di wilayah cirebon merupakan bukti bahwa komunitas Satya Gaura Svara Choir adalah komunitas paduan suara yang Eksis di wilayah cirebon.

\section{Peran Budaya Organisasi dalam} Keberhasilan Menjaring Anggota Baru Komunitas paduan Suara Satya Gaura Svara Choir (SGSC) Cirebon setiap

\footnotetext{
7Hasil wawancara dengan Silviyanti, pada hari rabu 28 Februari 2018 pada pukul 17.30 di Gedung Kesenian Rarasantang, Kota Cirebon
}

tahun mengagendakan open recruitment untuk calon anggota baru. Open recruitment diadakan untuk mengisi posisi keanggotaan yang telah ditinggalkan oleh anggota yang telah memutuskan untuk keluar karena alasan telah selesainya masa studi di perguruan tinggi atau karena telah memiliki kesibukan yang lain.

Mengenai keanggotaan, hal ini telah diatur dalam AD/ART Komunitas. Dimana keanggotaan harus melalui tahap tahap tertentu yang telah ditentukan, diataranya adalah harus mengikuti audisi dan wawancara dalam proses open recruitment. Setiap tahun, 50 sampai 70 orang tercatat telah mengikuti proses open recruitment, meski yang berhasil lolos dan bertahan hanya berkisar 20 orang saja.

Keberhasilan dalam merekrut anggota baru tidak terlepas dari nilai orientasi terhadap proses yang cukup ditekankan dalam komunitas tersebut. Diharapkan para anggota baru yang terpilih memiliki komitmen yang kuat terhadap komunitas paduan suara Satya Gaura Svara Choir Cirebon.

Hal ini sebagaimana yang diungkapkan oleh Informan 5.

"Kita setiap tahun pasti ngadain yang namanya oprec (open recruitment) untuk nyari anggota baru. Alhamdulillah sih, setiap tahun banyak yang daftar, ada 50 sampai 70 orang yang daftar setiap 
tahun. Tapi yang bertahan sih biasanya dua puluhan orang saja. Karena kan kita tuh butuh anggota yang punya basic paduan suara yah, walaupun sedikit juga, nggak yang baru belajar banget, sama tentunya yang mau berkomitmen dengan SGSC. Dan alhamdulillah. Anggota SGSC masih stabil, masih solid dan masih tetap rutin latihan"8

Selain itu, peran akun Instagram sebagai media informasi dan promosi juga cukup berperan dalam mempromosikan kegiatan open recruitment yang dilakukan oleh komunitas tersebut.

Hal tersebut menunjukan bahwa Budaya Organisasi pada komunitas Satya Gaura Svara Choir (SGSC) Cirebon telah berperan dalam mempertahankan jumlah anggotanya dengan melakukan kegiatan open recruitment anggota baru yang diadakan setiap tahunya dan menunjukan bahwa komunitas tersebut adalah komunitas yang masih eksis.

\section{Peran Budaya Organisasi dalam Proses Manajemen}

Sebagaimana yang telah dijelaskan pada BAB III, komunitas paduan suara Satya Gaura Svara Choir (SGSC) Cirebon merupakan komunitas yang terorganisasi dan terstruktur. Dimana terdapat pengurus dan anggota. Dalam struktur

\footnotetext{
8 Hasil wawancara dengan Dika Dani Septiati pada hari senin 26 Februari 2018 pukul 17.30 di Gedung Kesenian Rarasantang Kota Cirebon
}

kepengurusan, pengurus terdiri dari ketua, sekertaris dan bendahara serta divisi divisi yang dikepalai oleh seorang pengurus yang menangani masalah tertentu.

Struktur organisasi serta Uraian tugas masing masing pengurus dan anggota juga telah dicantumkan pada AD/ART Komunitas dan Tugas Pengurus telah dipahami oleh seluruh anggota sebagai salah satu aturan yang mengikat dan mempertegas anggota dalam merespon lingkungan ${ }^{9}$.

\section{Peran Budaya Organisasi Atas Prestasi}

\section{Komunitas}

Tujuan terbentuknya komunitas paduan suara menurut salah seorang pendiri Komunitas paduan suara Satya Gaura Svara Choir (SGSC) Sdri. Silviyanti ada tiga, yaitu; (1) untuk kegiatan ibadah. Sebagaimana yang dilakukan oleh kelompok kelompok paduan suara gereja, (2) untuk dikompetisikan. Sebagaimana yang dilakukan oleh kelompok kelompok paduan suara kampus yang sekolah yang sering mengikuti kompetisi paduan suara, dimana tolok ukur kesukseksesanya ketika memenangkan atau menjadi juara pada kompetisi tersebut. (3) untuk dipentaskan. Yaitu kelompok paduan suara yang tidak bertujuan untuk kegiatan

\footnotetext{
9 Hasil Observasi peneliti terhadap komunitas paduan suara Satya Gaura Svara Choir (SGSC) Cirebon pada bulan februari 2018
} 
ibadah atau berkompetisi di sebuah ajang tertentu, namun murni semata sebagai pengisisi acara yang menampilkan pertunjukan paduan suara di depan khalayak untuk menghibur.

Anggota komunitas seringkali mengidentifikasi komunitas mereka sebagai kelompok paduan suara yang bukan untuk kegiatan ibadah atau untuk berkompetisi, tetapi hanya untuk menampikan keterampilanya dalam mengolah suara dan memadukanya dengan suara anggota yang lain sesuai porsi dan komposisinya masing masing. Maka dari itu, tolok ukur dalam menilai kesuksesanya adalah ketika mereka sukses menampilkan paduan suara sebagai seni pertunjukan di depan banyak orang.

Dengan adanya kegiatan rutin latihan, anggota dapat mengasah ketrampilanya dalam memahami paduan suara. Dan sebagai kelompok paduan suara untuk dipentaskan, peran latihan rutin sangat penting dalam kelompok paduan suara. Karena hal tersebut akan memperlihatkan kualitas paduan suara di atas pentas.

\section{Peran Budaya Organisasi dalam}

\section{Menonjolkan Produk Sanggar}

Produk sanggar yang dimiliki oleh komunitas paduan suara Satya Gaura Svara Choir (SGSC) Cirebon tentunya adalah paduan suara. Sama halnya dengan seni teater, seni musik dan seni tari, paduan suara juga merupakan sebuah seni pertunjukan yang melibatkan kelompok di suatu tempat dan ditonton oleh banyak orang.

Sebagai sebuah komunitas paduan suara pertama dan satu satunya yang ada di wilayah Cirebon, tentunya komunitas tersebut memiliki keistimewaan dibanding kelompok paduan suara yang dimiliki oleh kampus, sekolah maupun gereja. Karena tidak terikat oleh lembaga atau instansi, maka dari itu mereka lebih mudah mengenalkan dan mengembangkan seni paduan suara kepada masyarakat luas.

Dengan peran akun Instagram sebagai media promosi dan seringnya kelompok Satya Gaura Svara Choir (SGSC) Cirebon diundang untuk pentas dengan mengenakan kostum tradisional daerah, maka sudah cukup banyak masyarakat yang mengetahui keberadaanya sebagai sebuah komunitas paduan suara.

Hal ini sebagaimana yang diungkapkan oleh Informan 3.

"sekarang banyak orang yang kenal dengan SGSC, kita kan sering juga diundang di acara acara talkshow di radio gitu, alhamdulillah responya bagus. Media media juga sering datang ngeliput kegiatan kita gitu. Jadi makin banyak orang yang kenal dengan SGSC, kenal juga bahwa di cirebon itu ada loh komunitas paduan suara. Komunitas yah, kalau kelompok paduan suara di kampus 
kampus atau sekolah sih udah banyak di cirebon. Tapi kalau komunitas yang gak terikat sekolah atau kampusnya dimana, ya di cirebon itu Cuma baru ada SGSC"10

\section{Dari hasil Observasi serta} wawancara yang telah dilakukan oleh peneliti dapat disimpulkan bahwa komunitas Satya Gaura Svara Choir (SGSC) Cirebon telah berhasil menonjolkan produknya yaitu seni paduan suara sebagai seni pertunjukan kepada masyarakat. Dan budaya organisasi seperti akun Instagram dan aksesoris yang dikenakan saat pentas maupun kegiatan sehari turut berperan dalam memperkenalkan komunitas Satya Gaura Svara Choir (SGSC) Cirebon sebagai sanggar paduan suara.

\section{Peran Budaya Organisasi Terhadap}

\section{Penerimaan Masyarakat}

Sejak dibentuk pada bulan november tahun 2014, komunitas Satya Gaura Svara Choir (SGSC) Cirebon telah melakukan puluhan kali pertunjukan sebagai pengisi acara, baik yang diselenggarakan oleh masyarakat umum, maupun juga yang diselenggarakan oleh lembaga atau instansi pemerintahan. Hal tersebut membuktikan bahwa seni pertunjukan paduan suara serta komunitas

10 Hasil wawancara dengan Fifta Haifa, pada hari rabu tanggal 28 Februari pukul 16.00 di Gedung Kesenian Rarasantang Kota Cirebon
Satya Gaura Svara Choir (SGSC) Cirebon merupakan komunitas yang telah diterima dengan baik ditengah tengah masyarakat.

Kepercayaan yang diberikan masyarakat tidak terlepas dari peran aturan latihan rutin serta nilai nilai kedisiplinan yang membetuk komunitas Satya Gaura Svara Choir (SGSC) Cirebon sebagai kelompok paduan suara profesional. Sebagaimana yang diungkapkan oleh Informan ${ }^{1}$

"Contohnya ya.. waktu kita kerja sama dengan paduan suara SMAN 7 Cirebon kita harus on time tepat waktu. Kelompok paduan suara SMAN 7 Cirebon itu kan sudah bagus ya.. ya jangan sampai kita sebagai mahasiswa dianggap kelompok paduan suara yang biasa biasa aja. Atau bahkan dianggap buruk oleh mereka. Itu kita tidak mau",11

\section{PENUTUP}

Berdasarkan hasil penelitian yang telah peneliti uraikan pada bab sebelumnya, maka kesimpulan dari penelitian Budaya Organisasi pada Komunitas Paduan Suara Satya Gaura Svara Choir (SGSC) Cirebon dalam menjaga Eksistensinya adalah sebagai berikut ;

Budaya Organisasi di Komunitas Satya Gaura Svara Choir (SGSC) Cirebon bisa dikatakan telah memiliki konsep

\footnotetext{
11 Hasil wawancara dengan Toni Damasah Wijaya, pada hari senin 19 Februari 2018 puku 11.00 di Kampus IAIN Syekh Nurjati Cirebon
} 
yang baik. Hal ini bisa dilihat berdasarkan level budaya organisasi yang meliputi artefak, norma, nilai nilai serta asumsi. Untuk mempertahankan eksistensinya, komunitas SGSC membuat identitas tersendiri untuk membedakan mereka dengan kelompok atau komunitas lainya. Dalam menjalankan organisasi, AD/ART Komunitas merupakan aturan yang harus ditaati oleh seluruh anggota. Nilai nilai yang yang diterapkan oleh anggota komunitas paduan suara Satya Gaura Svara Choir (SGSC) Cirebon meliputi nilai kebersamaan, dan kedisiplinan. Sementara itu, asumsi yang mendasari nilai nilai dan budaya organisasi di komunitas paduan suara Satya Gaura Svara Choir (SGSC) Cirebon adalah keyakinan bahwa komunitas tersebut merupakan sebuah keluarga. Serta keyakinan bahwa latihan sebagai kegiatan yang dapat membantu komunitas dalam mencapai tujuanya. Namun demikian, dalam prosesnya, AD/ART yang menjadi norma masih banyak anggota yang melanggar dan tidak ditindak tegas. Selain itu nilai nila kedisiplinan yang menjadi salah satu nilai yang ditekankan, malah masih banyak anggota yang tidak mengamalkan nilai nilai tersebut.

Meski begitu, Budaya Organisasi di Komunitas Paduan Suara Satya Gaura Svara Choir (SGSC) Cirebon yang diterapkan dan diyakini dapat dikatakan turut membantu eksistensi komunitas tersebut. Eksistensi yang dimaksud berupa Keberhasilan dalam mempertahankan dan memajukan komunitas, Keberhasilan dalam menjaring anggota, berjalanya fungsi manajemen, Keberhasilan dalam prestasi yang diperoleh, Dapat menonjolkan produk sanggar kepada masyarakat, serta Dapat diterima oleh masyarakat.

\section{DAFTAR PUSTAKA}

Afryanto, Suhendi. 2013, Internalisasi Nilai Kebersamaan melalui Pendidikan Pembelajaran seni Gamelan (pendidikan karakter bagi mahasiswa) Jurnal seni dan budaya panggung Vol 23 No 1 Maret 2013

Arni, Muhammad. 2006. Komunikasi

Organisasi, Jakarta, Bumi Aksara.

Bungin, Burhan. 2001. Metodologi penelitian sosial format kuantitatif dan kualitatif, Surabaya. Universitas Airlangga Press.

Bungin, Burhan. 2007. Penelitian Kualitatif, Jakarta, Kencana Prenada Media Grup.

Bungin, Burhan. 2013. Sosiologi Komunikasi, Jakarta, Kencana Prenada Media Grup.

Chatab, Nevrizond. 2007, Profil Budaya Organisasi mendiagnosis budaya dan merangsang perubahanya, Bandung, Allfabeta

Erma Lutfyana, "Eksistensi Tari Lawet di Kabupaten Kebumen" Fakultas Bahasa dan Seni Universitas Negeri Yogyakarta. (PDF).

Gunawan, imam. 2015. Metode Penelitian Kualitatif : Teori dan Praktek, Jakarta. Bumi Aksara. 
Hafid Safi'i, "Budaya Organisasi di Kantor Urusan Agama Kecamatan Seyegan Kabupaten Sleman" Fakultas Dakwah dan Komunikasi UIN Kalijaga Yogyakarta.

Hicks, Herbets G \& G. Ray Guliet, 1996. Organisasi dan teori tingkah laku, Jakarta, Sinar Grafika Offset http://digilib.uinsuka.ac.id/9622/1/BAB\%20I\%2C\% 20IV\%2C\%20DAFTAR\%20PUST AKA.pdf (PDF) http://lib.unnes.ac.id/22019/1/25019 14008-S.pdf (PDF)

https://www.itb.ac.id/news/read/5229/hom e/paduan-suara-mahasiswa-itb-juarai5th-florence-international-choirfestival-di-italia Diakses pada 26 januari 2018 pukul 10:40

Irawan, Ade \& Yiyik Dwi Pangesti. "Pengaruh Komunikasi Horizontal dan Budaya Organisasi terhadap Kinerja Karyawan Organisasi Jasa Keuangan di Batam”, Jurnal Akunnsi, Ekonomi dan Manajemen Bisnis, Vol 04 no. 2, Desember 2016,

http://lib.unnes.ac.id/22019/1/25019 14008-S.pdf (PDF).

Katuuk, Margareta Oktaviani dkk, 2016. Peran Komunikasi Organisasi dalam meningkatkan eksistensi Sanggar seni Vox Angelia, e journal acta diurna volume V no. 5 tahun 2016

Liliweri, Alo. 2004. Wacana Komunikasi Organisasi, Bandung: Mandar Maju.

Moleong, J Lexy. 2010. Metode Penelitian Kualitatif Cetakan ke dua puluh, Bandung. Remaja Rosdakarya Offset.

Mulyana, Deddy. 1990. Komunikasi Antar Pribadi Bandung, PT Remaja Rosda Karya.

Narullah, Rully. 2012. Komunikasi Antar Budaya di Era Budaya Siber, Yogyakarta, Kencana.

Ngalimun. 2016. Ilmu Komunikasi sebuah pengantar praktis, Yogyakarta, PT. Pustaka Baru Press.
Paduan Suara Mahasiswa ITB Juarai 5Th Florence International Choir Festival di Italia

Parmiyati, Ari. 2013 "Identifikasi Penyebab Rendahnya Kedisiplinan Siswa Kelas V SD Negeri Salam 1 Kecamatan Salam Magelang Tahun Ajaran 2013/2014" Fakultas Ilmu Pendidikan Unversitas Negeri Yogyakarta

Pawito. 2007. Penelitian Komunikasi Kualitatif. Jakarta: LKIS Pelangi Aksara.

Raco, JR, 2010. Metode penelitian Kualitatif jenis karakteristik dan keunggulanya, Jakarta, Grasindo.

Rahman Indra, Paduan Suara Indonesia The Resonanz Raih Juara Umum di Roma

https://www.cnnindonesia.com/hibura n/20170709172238-241-

226642/paduan-suara-indonesia-the-

resonanz-raih-juara-umum-di-roma

Diakses pada 26 januari 2018 pukul 10:24

Robbins. 2003. Organization Behavior, Concept Controversi and Applications. Prentice Hall Inc. USA. Terjemah. Jakarta: PT Indeks Kelompok Gramedia.

Sanggar Seni https://id.wikipedia.org/wiki/Sanggar seni diakses pada 09 april 2018

Schein, Edgar H. 1985. Organizational Culture and Leadership, San Fransisco. Jossey Bass Publisher.

Sendjaja, Djuarsa. 1994. Teori Komunikasi, Universitas Terbuka.

Setyodarmodjo, S., 2002. Daya dan Pekerti Manusia Sesuai Ajaran Jawa. Lembaga Javanologi. Surabaya

Sobirin, Achmad. 2007. Budaya Orgaisasi pengertian makna dan aplikasinya dalam kehidupan organisasi, Yogyakarta. STIM YPKN.

Soetopo, Hendiyat. 2016. Perilaku Organisasi, Bandung, PT Remaja Rosdakarya 
Sopiah. 2008. Perilaku Organisasi. Yogyakarta. ANDI.

Sri Handayani, "Upaya Pelestarian Eksistensi Kesenian Barongan Setyo Budoyo di Desa Loram Wetan Kecamatan Jati Kabupaten Kudus", Fakultas Bahasa dan Seni Universitas Negeri Malang.

Sugiyono. 2009. Metode Penelitian Kualitatif Kuantitaif dan $R \& D$, Bandung, Alfabeta.

Sugiyono. 2010. Metode Penelitian Pendidikan Metode Kuantitatif kualitatif dan $R \& D$, Bandung, Alfabeta.

Suharsimi, Arikunto. 2010. Prosedur penelitian suatu pendekatan praktik, Jakarta, Rineka cipta.

Suprayogo, Imam dan Tabroni, 2003. Metode Penelitian Sosial Agama, Bandung Remaja Rosdakarya,.

Tanzeh, Ahmad. 2009. Pengantar Metode

Penelitian, Yogyakarta: Teras,

Tika, Moh. Pabundu. 2006. Budaya Organisasi dan peningkatan Kinerja Perusahaan, Jakarta. PT Bumi Aksara,

Uchajana, Onong. 1993. Dinamika Komunikasi, Bandung, PT Remaja Rosdakarya.

Widjaja, A.W. 1985. Pedoman PokokPokok dan Materi Perkuliahan Pancasila di Perguruan Tinggi. Jakarta: Akademika Pressindo.

Wirawan. 2007. Budaya dan Iklim Organisasi, Jakarta., Salemba Empat. 